\title{
SIFAT FISIKA DAN ANALISIS GUGUS FUNGSI KARET SEAL O-RING DARI BAHAN TERMOPLASTIK ELASTOMER NITRILE BUTADIENE RUBBER (NBR) DAN POLYVINYL CHLORIDE (PVC)
}

\section{PHYSICAL PROPERTIES AND FUNCTIONAL GROUP ANALYSIS OF O-RING RUBBER SEALS FROM THERMOPLASTIC ELASTOMER NITRILE BUTADIENE RUBBER (NBR) AND POLYVINYL CHLORIDE (PVC)}

\author{
Arum Yuniari dan Nursamsi Sarengat \\ Balai Besar Kulit, Karet dan Plastik, Yogyakarta \\ Email: arumyuniari@yahoo.com \\ Diterima: 23 Februari 2013 Direvisi: 14 April $2013 \quad$ Disetujui: 14 Mei 2013
}

\begin{abstract}
The purpose of this research was to determine the physical properties and functional groups on O-ring rubber seals made of thermoplastic elastomers blend NBR and PVC. Composition of the NBR / PVC were successively varied: 90/10;85/15;80/20;75/25;70/30 and 65/35 phr. Mixing process between NBR/PVC with additive used a two roll mill within a temperature of $60^{\circ}-80^{\circ} \mathrm{C}$, the vulcanization process used a hydraulic press at a temperature of $170{ }^{\circ} \mathrm{C}$ and pressure of $150 \mathrm{~kg} / \mathrm{cm}^{2}$. The physical properties were evaluated including tensile strength, elongation at break, hardness, before and after aging, hardness after immersion in isooctane and swelling while analysis of functional groups was also carried out by method of Fourier Transform Infrared Spectrophotometer (FTIR). The result of the best vulcanized was characterized by tensile strength $188.93 \mathrm{~kg} / \mathrm{cm}^{2}$, the change of tensile strength after aging $2.50 \%$, elongation at break of $400 \%$, the change of elongation at break after aging was $12.5 \%$, hardness 75 shore $A$, the change of hardness after aging $0 \%$, the change of hardness after immersion in isooctane $1.3 \%$, swelling $0.8 \%$ and functional group of vulcanisate was indicated by new peak $(\mathrm{OH})$ at wave band of $3468 \mathrm{~cm}^{-1}$. Those formula met the requirements of the technical specifications of ASTMD 2000 seal O-ring.
\end{abstract}

Keywords: O-ring rubber seals, NBR, PVC, physical properties, functional group

\begin{abstract}
ABSTRAK
Tujuan penelitian ini adalah untuk mengetahui sifat fisika dan gugus fungsi karet seal $O$ ring yang dibuat dari bahan termoplastik elastomer campuran NBR dan PVC. Komposisi NBR/PVC divariasi berturut-turut 90/10; 85/15; 80/20; 75/25; 70/30 dan 65/35 phr. Pencampuran NBR/PVC dengan bahan tambahan (aditive) menggunakan two roll mill pada suhu $60^{\circ}-80^{\circ} \mathrm{C}$, proses vulkanisasi menggunakan hydraulic press pada suhu $170{ }^{\circ} \mathrm{C}$ dan tekanan 150 $\mathrm{kg} / \mathrm{cm}^{2}$. Pengujian sifat fisika karet seal O-ring meliputi tegangan putus, perpanjangan putus, kekerasan sebelum dan sesudah aging, kekerasan setelah perendaman dalam isooktan, swelling dan dilakukan juga analisis gugus fungsi dengan Fourier Transform Infrared Spectrophotometer (FTIR). Hasil uji vulkanisat terbaik sebagai berikut: tegangan putus $188,93 \mathrm{~kg} / \mathrm{cm}^{2}$, perubahan tegangan putus sesudah aging $2,50 \%$, perpanjangan putus $400 \%$, perubahan perpanjangan putus sesudah aging $12,5 \%$, kekerasan 75 shore A, perubahan kekerasan sesudah aging $0 \%$, perubahan kekerasan sesudah perendaman dalam isooktan 1,3\%, swelling $0,8 \%$ dan muncul gugus fungsional baru $\mathrm{OH}$ pada bilangan gelombang $3468 \mathrm{~cm}^{-1}$. Karet seal O-ring tersebut memenuhi persyaratan ASTMD 2000 tentang spesifikasi teknis seal O-ring.
\end{abstract}

Kata kunci: seal O-ring, NBR, PVC, sifat fisika, gugus fungsi 


\section{PENDAHULUAN}

Seal O-ring merupakan salah satu komponen penting dalam permesinan yang berfungsi sebagai penyekat untuk mencegah kontaminasi pada ruang yang bertekanan yang berisi bahan cair. Seal O-ring dirancang diletakkan pada alur yang terkompresi dan membuat segel antar muka. Seal O-ring dapat digunakan pada kondisi statis ataupun dinamis termasuk untuk poros pompa berputar dan piston silinder hidraulik. Seal O-ring berfungsi mencegah kebocoran fluida hidraulic dan kontaminasi ke sekelilingnya. Karakteristik khusus dari seal O-ring adalah pada bahan elastomer yang digunakan untuk pembuatan seal O-ring, dan beberapa persyaratan teknis yang mendukung antara lain: ketahanan kikis, ketahanan terhadap fluida, ketahanan terhadap tekanan mekanik. Adapun bentuk karet seal O-ring yang lazim dijumpai dipasaran seperti disajikan pada Gambar 1.

Faktor-faktor yang berpengaruh terhadap umur pakai dari seal O-ring, dan salah satu yang paling kritis adalah bahan baku dari seal O-ring itu sendiri. Elaheh (2009) melaporkan bahwa seal O-ring yang dibuat dari campuran Ethylene-Propylene-DieneMonomer (EPDM), Nitrile Butadiene Rubber (NBR) dengan ditambah filler nanoclay memberikan hasil compression baik. Penambahan filler organo-montmorillonite pada campuran NBR dan PVC dihasilkan vulkanisat dengan sifat swelling baik (Li, et al., 2010). Penggunaan serbuk PVC pada kompon NBR sangat efektif untuk menaikkan stabilitas termooksidasi NBR dari serangan

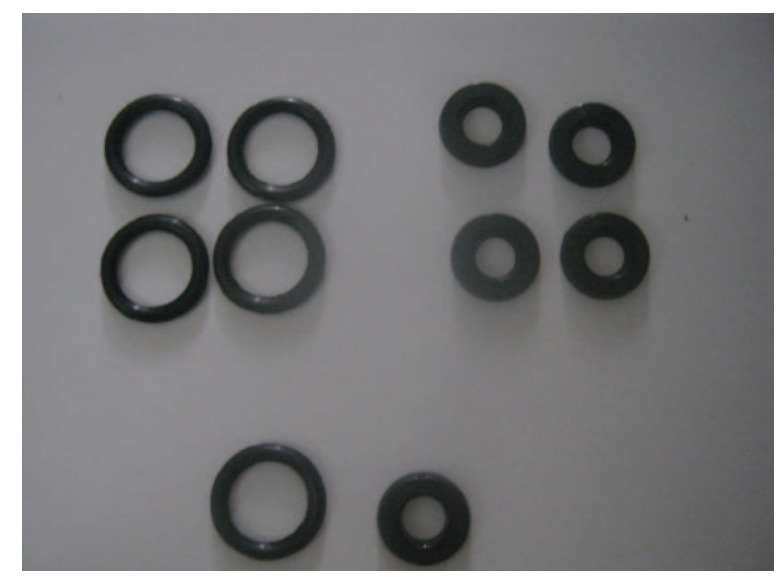

Gambar 1. Seal O-ring untuk rem mobil ozon (Noor, et al., 2010). Penambahan serbuk kayu pada campuran NBR dan PVC terbukti menurunkan sifat termal (Mousa et al., 2012). Pada penelitian ini dibuat seal O-ring dari bahan PVC dan NBR. Ketersediaan PVC di Indonesia menurut Indratmoko (2009) disuplai oleh 5 (lima) produsen PVC antara lain: PT Asahimas Chemical (Cilegon, Banten), PT TPC Indovyl (Gresik, Jawa Timur), PT Statomer (Merak, Banten), PT Sulfindo Adi Usaha (Bojonegara, Banten) dan PT Eastern Polymer (Tanjung Priuk, DKI Jakarta). Produksi PVC tahun 2011 ditargetkan sebesar 595 ton per tahun (Haraito, 2010). PVC termasuk jenis plastik dengan penggunaan sangat luas dan mampu memenuhi spesifikasi produk yang diinginkan. Beberapa keunggulan PVC adalah kuat, tahan lama dan tahan terhadap berbagai bahan kimia seperti asam, basa kuat, pelarut organik dan ozon. Campuran polimer antara NBR dan PVC merupakan polimer yang saat ini dikembangkan menjadi suatu polimer baru dan diharapkan penggunaannya didalam industri sangat luas. NBR mempunyai keunggulan dalam ketahanan terhadap oli dan mudah larut dengan PVC. NBR mempunyai ketahanan terhadap cuaca (weathering) dan ozon yang rendah (Jovanović, et al., 2009; Manoj, et al., 2011). Campuran polimer antara NBR dan PVC diharapkan mempunyai sifat fisika yang baik dan nilai komersial tinggi. NBR dan PVC apabila dicampur diharapkan dapat memperbaiki sifat fisika, thermal, dan pengurangan biaya produksi pada produk akhir. NBR dan PVC merupakan polimer yang sulit bercampur, agar kedua polimer tersebut dapat bercampur sempurna digunakan kompatibiliser dan inisiator. Kompatibiliser merupakan senyawa spesifik yang digunakan untuk memadukan polimer yang tidak kompatibel menjadi campuran yang stabil melalui ikatan "intermolekuler". Prinsip kerja dari kompatibilser merupakan kombinasi dari mekanisme berikut, yakni mengikatkan bahan kompatibiliser tersebut pada satu komponen campuran melalui grafting kimiawi dan membentuk "polymeric tail" yang larut dalam komponen lain. Insiator yang digunakan adalah jenis peroksida yang berfungsi mencangkokkan anhidrat ke rantai polimer. Husodo et al. (2010) membuat 
seal O-ring dari campuran karet alam dan NBR. Campuran antara termoplastik dan karet (elastomer) menghasilkan suatu material yang disebut termoplastik elastomer. Termoplastik elastomer dari campuran PVC dan NBR telah diteliti oleh Xiang et al. (2008) dan Passador et al. (2008). Adapun tujuan penelitian ini adalah untuk mengetahui sifat fisika dan gugus fungsi dari seal O-ring dari bahan termoplastik elastomer campuran NBR dan PVC.

\section{BAHAN DAN METODE Bahan Penelitian}

Bahan penelitian terdiri atas karet NBR Krynac 4975 F dengan kadar acrylonitrile 48,5\%, viskositas Mooney (ML $\left.(1+4) 100^{\circ} \mathrm{C}\right)$ 75 , berat jenis $1,01 \mathrm{~g} / \mathrm{cm}^{3}$ dan PVC powder dengan $\mathrm{K}$ value 65 merk Fujichem, asam stearat 1,5 phr, zinc oxide ( $\mathrm{ZnO}) 3 \mathrm{phr}$, HAF Black (N-330) 40 phr, dioctyl phthalate (DOP) $25 \mathrm{phr}$, 2,2,4,trimethyl-1,2, dihydroquinoline (TMQ) 2 phr merk Kemai, mercaptobenzothiazole (MBTS) 1 phr buatan Shandong Sanxian China, tetramethylthiuram monosulphide(TMT) 0,5 phr merk Stairchem China, maleat anhidride (MA) 95\% $4 \mathrm{phr}$ merk Sigma Aldrich, dicumyl peroksida (DCP) 0,2 phr merk Varox, kalsium stearat 3 phr buatan Singapura merk FACI dan sulfur 1,5 phr merk MIDAS SP 325.

\section{Peralatan Penelitian}

Peralatan untuk penyiapan campuran polimer adalah: two roll mill, dan untuk proses vulkanisasi adalah Hydraulic Press MN Vulcanizing Press, Spec XLB, D 400 x 400 x1, Timbangan digital Mettler Toledo. Peralatan pengujian sifat stress dan strain adalah Tensile strength tester Merek Kao Tieh, model KT 7010A, Seri 70287 kapasitas $500 \mathrm{~kg}$, Hardness Tester merek Toyoseiki (Durometer D), Fourier Transform Infra Red (FTIR) merk Shimadzu IR Prestige 21.

\section{Metode Penelitian}

Pembuatan kompon karet seal $O$ ring dilakukan dengan variasi perbandingan NBR dan PVC berturut-turut: 90/10; 85/15; 80/20; 75/25; 70/30 dan 65/35. Masing-masing bahan ditimbang sesuai formula, selanjutnya bahan PVC, kalsium strearat, dicumyl peroksida dan maleat anhidrat dicampur dengan mixer selama 10 menit (Campuran A). NBR digiling dengan two roll mill suhu $60-80{ }^{\circ} \mathrm{C}$ hingga plastis. Campuran $\mathrm{A}$ dan aditive lainnya ditambahkan pada NBR berselang seling dengan DOP, hingga kompon bercampur sempurna. Sebelum sufur sebagai bahan pemvulkanisasi ditambahkan, kompon diambil dari two roll mill, didinginkan selama 3-5 menit, dilanjutkan penggilingan kompon sambil ditambahkan sulfur, setelah campuran homogen kompon diambil dari two roll mill, didinginkan dan dimasukkan dalam ruang kondisi dengan suhu $23 \pm 2^{\circ} \mathrm{C}$ selama 24 jam. Kompon divulkanisasi menggunakan hydraulic press pada suhu $170^{\circ} \mathrm{C}$ dan tekanan $150 \mathrm{~kg} / \mathrm{cm}^{2}$ dan waktu sesuai rheometer.

\section{Pengujian karet seal $O$-ring dari bahan termoplastik elastomer NBR dan PVC}

Untuk mengetahui kualitas karet seal $O$ ring dilakukan pengujian sesuai ASTM D 2000 yang meliputi: tegangan putus, perpanjangan putus, perubahan tegangan putus, perpanjangan putus dan kekerasan setelah aging pada suhu $100^{\circ} \mathrm{C}$ selama $70 \mathrm{jam}$, perubahan kekerasan setelah perendaman dalam isooktan dan swelling (ASTM, 1999). Gugus fungsi vulkanisat dianalisa dengan Fourier Transform Infra Red (FTIR).

\section{HASIL DAN PEMBAHASAN}

Pengaruh komposisi NBR/PVC terhadap sifat fisika karet seal $O$ - ring dapat dilihat pada Gambar 2 sampai dengan Gambar 6.

\section{Tegangan putus karet seal O-ring sebelum dan sesudah aging.}

Tegangan putus seal O-ring sebelum dan sesudah aging disajikan pada Gambar 2. Pengusangan vulkanisat dimaksudkan untuk mengetahui perubahan sifat fisika dari vulkanisat setelah mendapat perlakuan pemanasan pada suhu tertentu. Pengusangan dilakukan pada suhu $100^{\circ} \mathrm{C}$ selama 70 jam. Hasil uji tegangan putus menunjukkan jumlah PVC pada vulkanisat karet seal O-ring makin besar, tegangan putus cenderung turun. Hal ini disebabkan PVC bersifat rigid vulkanisat menjadi kaku dan rapuh sehingga memberikan 
dampak penurunan tegangan putus, hasil ini sesuai penelitian dari (Rojek and Stabik, 2007; Noor et al., 2010; Rozik and Abd-ElMesssih, 2010). Vulkanisat dengan komposisi NBR/PVC (90/10) phr hingga NBR/PVC $(65 / 35)$ phr nilai tegangan putus berkisar: 204,52-189,51 kg/ $\mathrm{cm}^{2}$. Campuran polimer PVC/NBR (70/30) hasil penelitian dengan carbon black $40 \mathrm{phr}$ menghasilkan tegangan putus sebesar $187,9 \mathrm{~kg} / \mathrm{cm}^{2}$, nilai ini lebih tinggi dibandingkan hasil penelitian yang dilakukan oleh (Cancarb, 2009) dengan komposisi PVC/NBR (70/30) ditambah thermal black $\mathrm{N}$ 990. Tegangan putus vulkanisat seal $O$-ring setelah mendapat perlakuan aging akan mengalami penurunan sifat yang disebabkan oleh pemutusan ikatan rangkap dari polimer tersebut sehingga terjadi proses degradasi.

Sifat tegangan putus vulkanisat sesudah aging menunjukkan makin besar jumlah PVC yang ditambahkan pada vulkanisat seal O-ring perubahan tegangan putus setelah aging cenderung turun, dengan demikian dapat dikatakan ketahanan usangnya makin baik. Vulkanisat dengan kandungan NBR/PVC (70/30) merupakan campuran polimer sesudah aging mempunyai nilai tegangan putus sebesar $186,5 \mathrm{~kg} / \mathrm{cm}^{2}$. Bila dibandingan dengan tegangan putus awal maka komposisi tersebut mempunyai perubahan tegangan putus terkecil yaitu sebesar $0,74 \%$, hal ini menunjukkan dispersi resin PVC kedalam polimer karet cukup sempurna. Hasil uji perubahan tegangan putus untuk semua

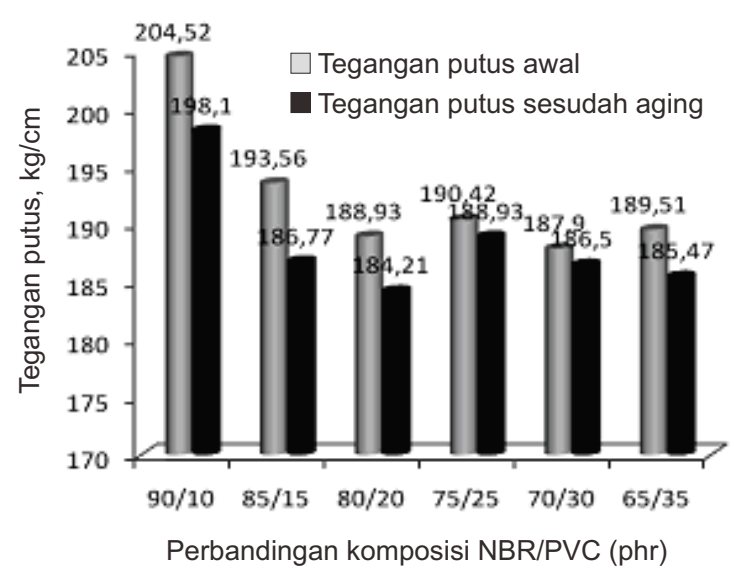

Gambar 2. Pengaruh perbandingan komposisi NBR/PVC terhadap sifat tegangan putus sebelum dan sesudah aging komposisi NBR/PVC adalah: 0,74 3,14\%, sedangkan persyaratan seal-O ring dari ASTM D. 2000 sebesar $30 \%$. Oleh sebab itu penambahan PVC membuktikan ketahanan terhadap pengusangan makin baik.

\section{Perpanjangan putus karet seal $O$-ring sebelum dan sesudah aging}

Perpanjangan putus vulkanisat karet sangat dipengaruhi sifat dasar dari polimer itu sendiri. Hasil uji perpanjangan putus disajikan pada Gambar 3, perpanjangan putus campuran polimer NBR/PVC, turun dengan bertambahnya jumlah PVC. Kenaikan jumlah PVC, ternyata berdampak pada penurunan perpanjangan putus. Hal ini kemungkinan disebabkan oleh NBR yang bersifat elastis sedang PVC bersifat keras dan kaku (Noor et al., 2010). Hasil uji perpanjangan putus terkecil dijumpai pada vulkanisat NBR/PVC $(65 / 35)$ phr yaitu sebesar $340 \%$. Semua hasil uji perpanjangan putus vulkanisat yang dibuat dari campuran polimer NBR dan PVC memenuhi persyaratan ASTM D 2000. spesifikasi teknis seal O-ring yang mensyaratkan sebesar minimal 250\%. Penentuan perubahan perpanjangan putus setelah aging dimaksudkan untuk mengetahui nilai perubahan perpanjangan putus sebelum dan setelah aging.

Makin tinggi jumlah PVC yang digunakan perubahan perpanjangan putus setelah aging

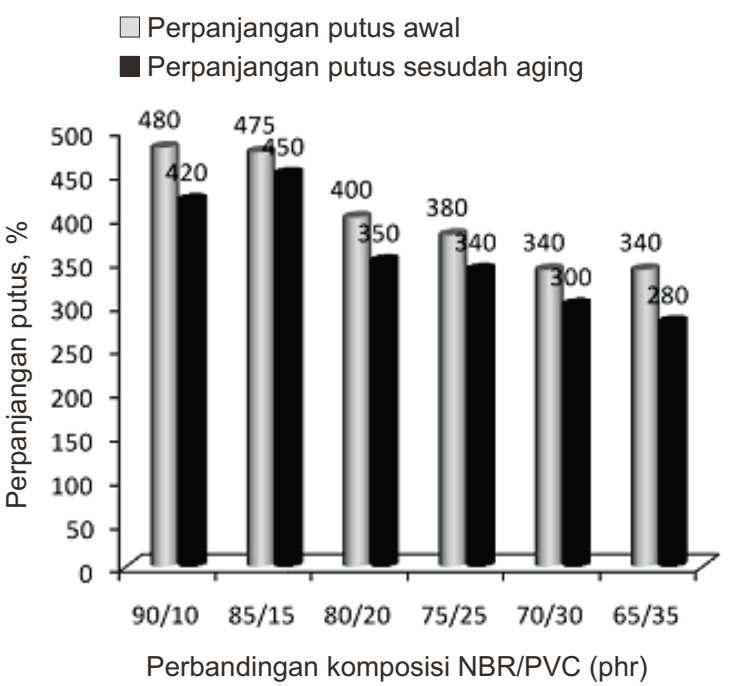

Gambar 3. Pengaruh komposisi NBR/PVC terhadap sifat perpanjangan putus sebelum dan sesudah aging 
turun secara nyata. Perubahan perpanjangan putus terkecil dijumpai pada vulkanisat dengan campuran polimer NBR/PVC $(85 / 15)$ phr dan sebesar 5,26\%. Semua hasil uji perubahan perpanjangan putus setelah aging vulkanisat memenuhi persyaratan ASTM D 2000, Spesifikasi teknis seal O ring yang mensyaratkan sebesar maksimal 50\%.

\section{Kekerasan karet seal $O$-ring sebelum dan setelah aging}

Kekerasan merupakan salah satu parameter yang dipersyaratkan oleh produk seal O-ring. Gambar 4 menunjukkan pengaruh perbandingan NBR/PVC terhadap kekerasan vulkanisat seal $O$-ring sebelum dan sesudah aging.

Hasil penelitian menunjukkan bahwa makin turun jumlah NBR, kekerasan vulkanisat seal $O$-ring akan berkurang atau kekerasan naik dengan bertambahnya jumlah PVC. Hasil penelitian ini sesuai dengan pendapat dari Passador et al., (2008) dan Noor et al., (2010). Kekerasan yang memenuhi syarat adalah vulkanisat dengan perbandingan NBR/PVC: 90/10; 80/20; 75/25 dan 65/35. Penggunaan kompatibiliser maleat anhidrat ternyata berpengaruh terhadap kekerasan vulkanisat. Shokri, et al. (2006) melaporkan bahwa penggunaan maleat ahidrat sebagai kompatibiliser dapat menurunkan kekerasan. Dari hasil penelitian tidak semua vulkanisat memenuhi persyaratan ASTM D 2000. Spesifikasi teknis seal $O$-ring yang dipersyaratkan sebesar $75 \pm 5$ shore A.

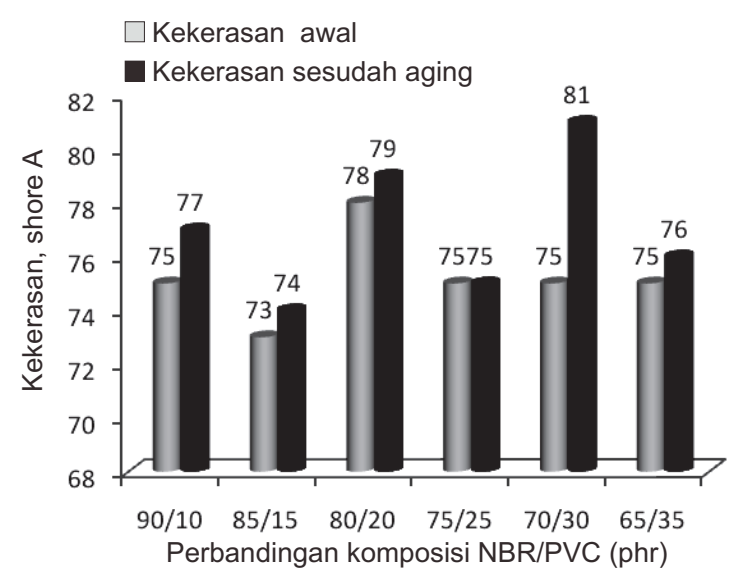

Gambar 4. Pengaruh komposisi NBR/PVC terhadap sifat perubahan kekerasan sesudah aging pada suhu $100^{\circ} \mathrm{C}$ selama 70 jam
Kekerasan vulkanisat campuran polimer NBR dan PVC setelah dipanaskan selama pada suhu $100^{\circ} \mathrm{C}$ selama 70 jam cenderung naik, dan vulkanisat bertambah keras akibat degradasi. Perubahan kekerasan vulkanisat seal O-ring antara $0-8 \%$. Vulkanisat dengan campuran NBR dan PVC (75/25) phr, merupakan vulkanisat yang tidak mengalami perubahan kekerasan setelah aging. Hal ini membuktikan penambahan PVC menyebabkan vulkanisat mempunyai ketahanan aging yang baik. Persyaratan perubahan kekerasan setelah aging pada suhu $100{ }^{\circ} \mathrm{C}$ selama 70 jam sesuai ASTM D 2000. Spesifikasi teknis seal O-ring adalah maksimum $15 \%$.

\section{Kekerasan karet seal $O$-ring sesudah perendaman dalam isooktan}

NBR dan PVC merupakan bahan yang larut dalam isooktan. Pengujian dengan perendaman dalam isooktan untuk mengetahui ikatan silang kimiawi dan adhesi ikatan silang antar muka. Karet alam maupun sintetis akan mengalami perubahan kekerasan setelah direndam dalam isooktan.

Grafik perubahan kekerasan setelah perendaman dalam isooktan disajikan pada Gambar 5. Hasil penelitian menunjukkan setelah dilakukan perendaman dengan isooktan, kekerasan cenderung naik dengan bertambahnya jumlah PVC. Dari 8 (delapan)

$\square$ Kekerasan awa

Kekerasan sesudah perendaman isooktan

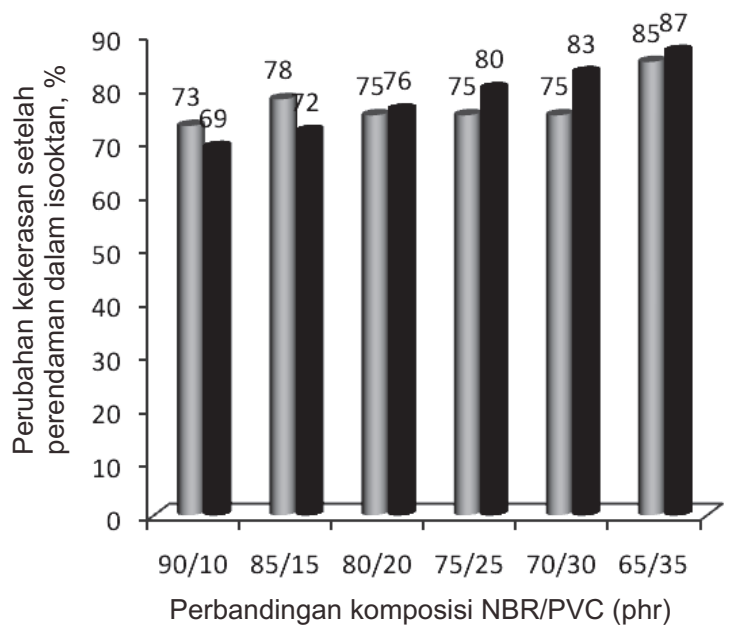

Gambar 5. Pengaruh komposisi NBR/PVC terhadap sifat kekerasan sesudah perendaman dalam isooktan 
formulasi vulkanisat dengan campuran polimer NBR/PVC $(90 / 10)$ adalah yang paling baik karena tidak mengalami perubahan kekerasan setelah perendaman dalam isooktan pada suhu $23^{\circ} \mathrm{C}$ selama 70 jam. Elastomer mengalami degradasi karena terjadi reaksi kimia dengan pelarut. Keberadaan gugus polar dalam rantai polimer dapat meningkatkan ketahanan terhadap isooktan. Selain itu makin tinggi tingkat ikatan silang vulkanisat makin kompatibel dan jumlah pelarut yang diserap sedikit sehingga seal O-ring tidak berubah kekerasannya. Hasil penelitian menunjukkan rentang perubahan kekerasan adalah $8-12 \%$. Persyaratan perubahan kekerasan sesudah perendaman dalam isooktan menurut ASTM D 2000. Spesifikasi teknis seal O-ring sebesar $10 \%$.

\section{Perubahan volume karet seal $O$-ring sesudah perendaman dalam isooktan (swelling)}

Proses swelling dalam vulkanisat karet merupakan proses difusi. Sejumlah pelarut terdifusi dalam karet sampai mencapai kesetimbangan. Gambar 6. menunjukkan ketahanan vulkanisat terhadap swelling sangat tinggi hal ini terlihat nilai swelling sangat rendah yaitu antara $0-2,53 \%$. Vulkanisat NBR/PVC (70/30) setelah direndam dalam isooktan pada suhu $23^{\circ} \mathrm{C}$ selama 70 jam perubahannya kecil yaitu $0 \%$, hal ini menunjukkan mobilitas pelarut tidak dapat menembus rantai polimer. Vulkanisat campuran polimer NBR dan PVC mempunyai ketahanan terhadap isooktan baik, sehingga dapat disimpulkan vulkanisat bercampur sempurna porositas kecil, jumlah isooktan yang di absorbsi sangat kecil. Derajat swelling dinyatakan dalam jumlah cairan (liquid) yang diserap oleh polimer (Abu-Abdeen and Elamer, 2010).

Swelling terjadi karena ekspansi polimer dan tersedianya free volume yang lebih banyak untuk memfasilitasi perpindahan massa pelarut. NBR merupakan kopolimer dari acrylonitril dan butadiene yang mempunyai sifat ketahanan terhadap oil baik. Kadar acrylontrile dalam kopolimer sangat mempengaruhi polaritas dan swelling resistance vulkanisat. Kadar acrylonitrile makin tinggi swelling tinggi. Swelling juga dipengaruhi oleh proses terbentuknya ikatan silang (cross linking). Dalam proses cross linking terbentuk gugus polar pada cabang cabangnya dan berdampak meningkatkan ketahanan terhadap swelling. Ikatan silang tersebut menghambat daya mulur rantai karet yang diinduksi oleh swelling, akibatnya difusi pelarut ke dalam celah ( $g a p$ ) diantara molekul karet menjadi sulit, sehingga menurunkan persentase swelling dan mencegah terjadinya pemutusan rantai (Indrajati dkk, 2012). Oleh karena itu, swelling dapat dikurangi dengan meningkatkan jaringan molekul karet, rendahnya nilai swelling menunjukkan derajad polimerisasi makin tinggi (Roslaili, et al., 2010). Penggunaan bahan NBR dengan kadar ACN 48,5\% membuktikan vulkanisat mempunyai sifat swelling yang baik. Perubahan volume yang dipersyaratkan oleh ASTM D 2000 spesifikasi teknis seal O-ring adalah maksimum 1,5.

\section{Analisa gugus fungsi campuran NBR dan PVC}

Fungsi analisa gugus fungsi untuk mengetahui ikatan silang, rangkap, tunggal dan bercabang dari suatu campuran polimer. Pada pembahasan ini disampaikan analisa gugus fungsi dari masing-masing polimer dan campuran keduanya. Hasil analisa gugus fungsi NBR disajikan pada Gambar 7. Gugus fungsi yang ada yaitu: acrylonitrile, bilangan gelombang $986 \mathrm{~cm}^{-1}$ adalah $\mathrm{CH}$ wagging dari trans $\mathrm{CH}=\mathrm{CH}$ unit.

Panjang gelombang dari polimer PVC disajikan pada Gambar 8. Menurut Bodirlau

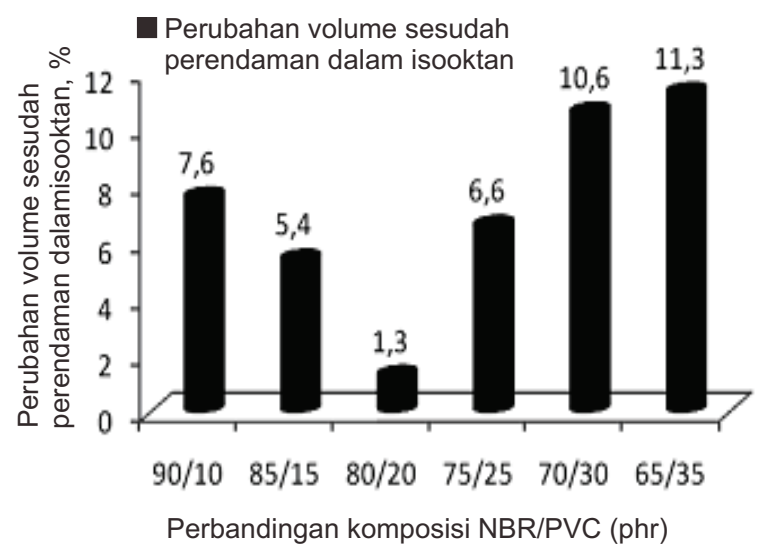

Gambar 6. Pengaruh komposisi NBR/PVC terhadap sifat swelling vulkanisat seal $O$-ring sesudah perendaman dalam isooktan 


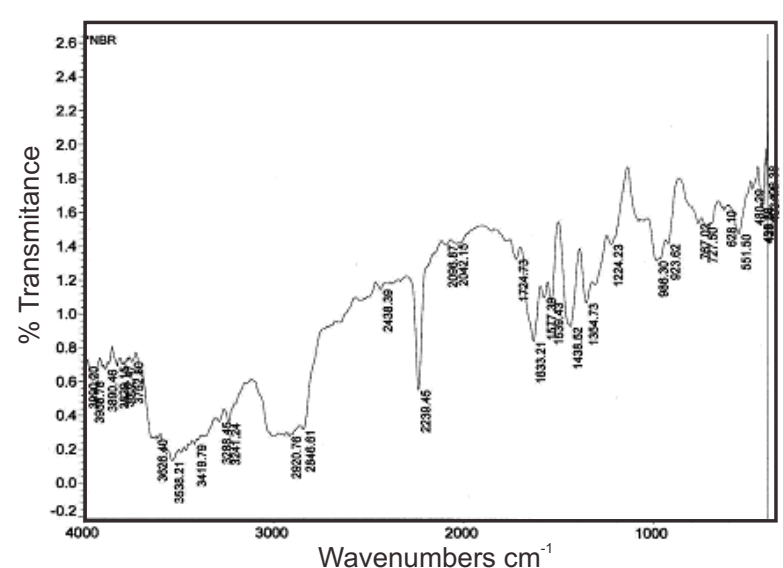

Gambar 7. Panjang gelombang polimer NBR yang ditentukan dengan FTIR

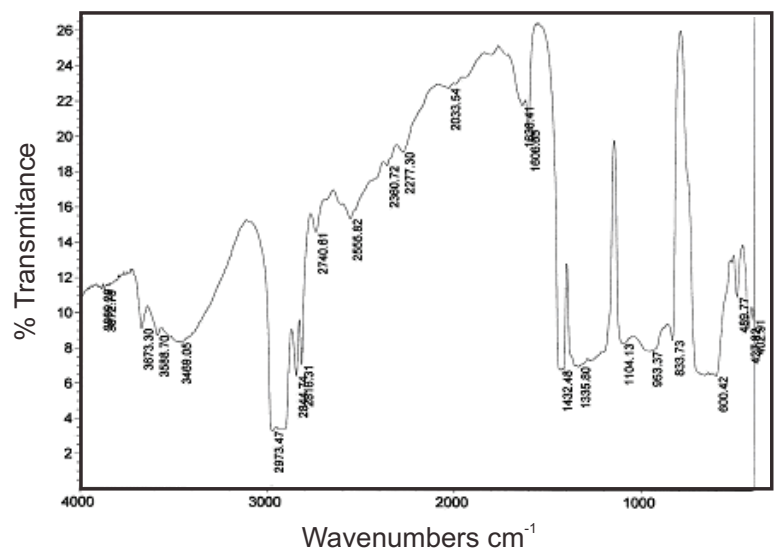

Gambar 8. Panjang gelombang polimer PVC yang ditentukan dengan FTIR

et al. (2009), spektum PVC menggambarkan pita serapan di daerah $2959 \mathrm{~cm}^{-1}$ (C-H stretching dari $\mathrm{CH}-\mathrm{Cl}), 2929 \mathrm{~cm}^{-1}(\mathrm{C}-\mathrm{H}$ stretching dari $\mathrm{CH}_{2}$ ), 1461 dan $1430 \mathrm{~cm}^{-1}$ (wagging $\left.\mathrm{CH}_{2}\right), 1332 \mathrm{~cm}^{-1}\left(\mathrm{CH}_{2}\right)$ deformasi, $1272 \mathrm{~cm}^{-1}(\mathrm{C}-\mathrm{H}$ stretching dari $\mathrm{CH}-\mathrm{Cl}), 1072$, $958 \mathrm{~cm}^{-1}$ (rocking $\mathrm{CH}_{2}$ ), 703, 639 dan 616 $\mathrm{cm}^{-1}(\mathrm{C}-\mathrm{Cl}$ stretching). Spektra PVC merk fujichem hasil penelitian adalah: bilangan gelombang $2973 \mathrm{~cm}^{-1}$ menunjukkan $\mathrm{C}-\mathrm{H}$ stretching dari $\mathrm{CH}-\mathrm{Cl} ; 2816,2824 \mathrm{~cm}^{-1} \mathrm{C}-\mathrm{H}$ stretching dari $\mathrm{CH}_{2} ; 1432 \mathrm{~cm}^{-1} \mathrm{CH}_{2}$ wagging $\mathrm{CH}_{2}$ dan $1335 \mathrm{~cm}^{-1} \mathrm{CH}_{2} \mathrm{CH}_{2}$ deformasi.

Panjang gelombang campuran polimer NBR/PVC dan maleat anhidrat disajikan pada Gambar 9. Hasil analisis spektroskopi menunjukkan terjadi gugus fungsi $\mathrm{C}=\mathrm{C}$ pada bilangan gelombang $1638 \mathrm{~cm}^{-1}$ dari struktur $\mathrm{MAH}$ dan $\mathrm{C}-\mathrm{C}$ radikal dari $\mathrm{MAH}$ graftingPVC, pada bilangan gelombang 3468

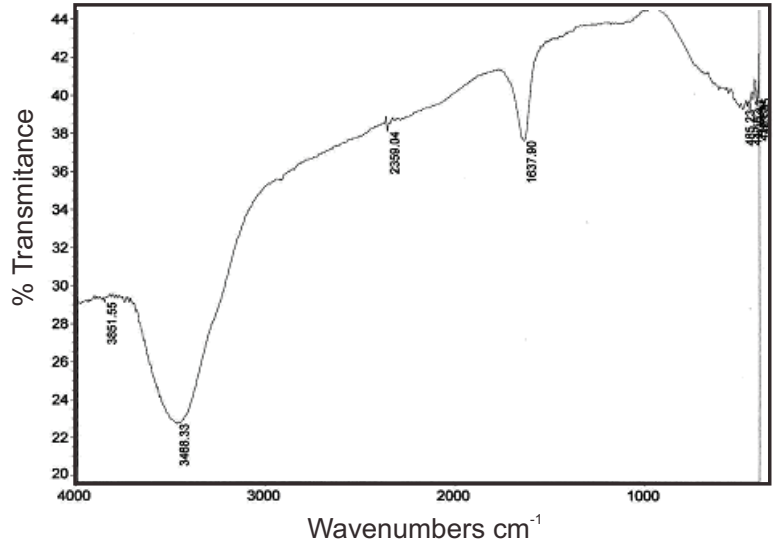

Gambar 9. Panjang gelombang polimer NBR/PVC (80/15) MAH 4 phr

terbentuk gugus fungsi baru $\mathrm{OH}$ stretching vibration diduga kuat hasil akibat reaksi grafting dengan MAH.

\section{KESIMPULAN}

Seal O-ring yang dibuat dari bahan termoplastik elastomer campuran antara NBR dan PVC mempunyai sifat fisika baik dan memenuhi persyaratan ASTM D 2000 spesifikasi teknis $O$-ring.

Komposisi campuran NBR dan PVC dengan sifat fisika terbaik sebagai berikut: NBR 80 phr, PVC 20 phr, MAH 4 phr, DOP 25 phr, Ca stearat 3 phr, ZnO 3 phr, asam stearat $1,5 \mathrm{phr}$, TMQ $2 \mathrm{phr}$, MBTS $1 \mathrm{phr}$, TMT 0,5 phr, DCP 0,2 phr, carbon black $40 \mathrm{phr}$ dan sulfur 1,5 phr.

Sifat fisika dari formulasi terbaik sebagai berikut:tegangan putus $188,93 \mathrm{~kg} / \mathrm{cm}^{2}$, perubahan tegangan putus sesudah aging $2,50 \%$, perpanjangan putus $400 \%$, perubahan perpanjangan putus sesudah aging 12,5\%, kekerasan 75 shore A, perubahan kekerasan sesudah aging $0 \%$, perubahan kekerasan sesudah perendaman dalam isooktan 1,3\% dan swelling $0,8 \%$.

Analisa gugus fungsi dengan FTIR terhadap vulkanisat terbukti terjadi reaksi antara PVC, NBR dan MAH didukung munculnya gugus fungsi baru $\mathrm{OH}$ pada bilangan gelombang $3468 \mathrm{~cm}^{-1}$.

\section{UCAPAN TERIMA KASIH}

Peneliti mengucapkan terima kasih kepada Bapak Subardi yang telah membantu pelaksanaan proses komponding dan kepada Bapak L. Triyono yang telah membantu dalam 
hal uji sifat fisika vulkanisat.

\section{DAFTAR PUSTAKA}

Abu-Abdeen, M. and Elamer, I., 2010. Mechanical and swelling properties of thermoplastic elastomer blends. Material and Design, 31: 808-815.

ASTM, 1999. ASTM D 2000 Technical Specification Seal O-ring.

Bodirlau, R, Teaca, C. A. and Spiridon, I., 2009. Preparation and characterization of composites comprising modified hardwood and wood polymers/ poly(vinyl chloride), BioResources, 4(4): 1285-1304.

Cancarb, 2009. Medium thermal carbon black in NBR/PVC rubber compound, Technical Bulletin, Cancarb, Canada.

Elaheh, G., 2009. Enhancement of the properties of EPDM/NBR elastomers using nanoclay for seal application, Journal Polymers Composites, 30(11): 1657-1667.

Haraito, G., 2010. Produsen lokal targetkan kenaikan PVC 5 persen di tahun 2011, Berita Industri, http://industri. kontan.co.id/news, diakses tanggal 3 Mei 2011

Husodo, N. Anzip, A. dan Suwarni, 2010. Pengaruh penambahan karet alam pada formula kompon karet oil seal terhadap ketahanan bocor, Laporan Penelitian, Teknik Mesin, Institut Teknologi Surabaya.

Indrajati, I. N., Dewi, I. R. dan Irwanto, D., 2012. Pengaruh variasi rasio $\mathrm{HAF} / \mathrm{SRF}$ terhadap sifat vulkanisat NBR, Majalah Kulit, Karet dan Plastik, 28(2): 59-68.

Indratmoko, 2009. Ketersediaan dan penggunaan bahan plastik PVC produksi dalam negeri, Handout Workshop Pengembangan Teknologi Bahan Baku/Komponen Lampu hemat energi, Direktorat Industri Elektronika dan Telematika, Jakarta.

Jovanović, V., Simendic, J. B., Jovanovic, S. S., Markovic, G. and Milena, M. C., 2009. The influence of carbon black on curing kinetics and thermal aging of acrylonitrile-butadiene rubber, Chemical Industry \& Chemical Engineering Quarterly, 15(4): 283-289.
Li, H., Wang, L., Song, G., Gu, Z., Li, P., Zhang, C. and Gao, L., 2010. Study of NBR/PVC/OMTT nanocomposites prepared by mechanical blending, Iranian Polymer Journal, 19(1): 39-46.

Manoj, K. C., Kumari, P. and Unnikrishnan, G., 2011. Cure properties, swelling behaviors and mechanical properties of carbon black filler reinforced EPDM/NBR blend system, Journal of Applied Polymer Science, 120: 26542662.

Mousa, A., Heinrich, G., Kretzschmar, B., Wagenknecht, U. and Das, A., 2012. Utilization of agrowaste polymer in PVC/NBR alloys: tensile, thermal and morphological properties, International Journal of Chemical Engineering, 2012.

Noor, A., Nor, M. and Madya, 2010. The potential of poly(vinyl chloride)(PVC) powder as a filler in acrylonitrile butadiene rubber (NBR) compounds; the effects on cure, flame retardant and mechanical properties, Final Project Report, Universiti Teknologi MARA, Shah Alam.

Passador, F. R., Rodolfo, A. and Pessan, I. A., 2008. Dynamic vulcanization of PVC/NBR blends, Proceedings of The Polymer Processing Society 24th Annual Meeting, The Polymer Processing Society, Salerno.

Xiang, P., Zhao, X. Y., Xiao, D. L., Lu, Y. L. and Zhang L. Q., 2008. The structure and dynamic properties of nitrile-butadiene rubber/poly(vinyl chloride)/hindered phenol crosslinked composites, Journal of Applied Polymer Science, 109: 106114.

Rojek, M. and Stabik, J., 2007. Butadieneacrylonitrile elastomers as PVC modifiers, Journal Archives of Materials Science and Engineering, 28(1): 41-48.

Roslaili, A. A., Nor, A. A. S., Nazry, M. S. and Nihla, A. K., 2010. Determination of structural and dimensional change of $\mathrm{O}-$ ring polymer/rubber seals immersed in oils, International Journal of Civil and Environmental Engineering, 10(5): 113.

Rozik, N. N. and Abd-El-Messieh, L. S., 2010. 
Physical studies on NBR/waste PVC blends reinforced with calcium carbonate and carbon black, Journal Kautschuk, Gummi, Kunststoffe, 63: 114-119.

Shokri, A. A., Gholamreza, B. and Tahereh, D. F., 2006. An investigation of mechanical and rheological properties of NBR/PVC blends: influence of anhydride addives, mixing procedure and NBR form, Iranian Polymer Journal , 15(3): 227. 
